\title{
Study determinants of increased Z-Score of Body Mass Index in preschool-age children
}

\author{
Fathi M. El-Gamal ${ }^{1 *}$, Rawan Babader ${ }^{2}$, Maha Al-Shaikh², Amani Al-Harbi², Jumana Al-Kaf ${ }^{2}$ and Wafa Al-Kaf ${ }^{1}$
}

\begin{abstract}
Objective: To determine the association between socioeconomic level, gender, stunting and other characteristics with the presence of overweight/obesity in the preschool children.

Result: BMI/Age Z score $>+2$ SD was found in $19.5 \%$ of the children. It was more common among the children from areas with high socio-economic level (OR: $2.43 ; 95 \% \mathrm{Cl} 1.54,3.84$, and $\mathrm{p}<.000)$. Obesity was higher among the males (OR 1.76; $95 \% \mathrm{Cl} 1.09,2.8$, and $\mathrm{p}<.02$ ) compared to females. The increased duration of breast feeding, was significantly associated with increased BMI/Age Z-score $(b=.027, p<.004)$. Decreased age of the child was significantly associated with increased BMI/Age Z-score $(b=-.013, p<.004)$. The children with stunted growth were 6.7 times fold likely to have BMI/Age Z Score $>+2$ SD compared to the normal children (OR 6.73; 95\% Cl 3.79, 10.80, and $\mathrm{p}<.000$ ), after allowing for other factors. No significant association was found between allergic disorders and BMI/Age Z score $>+2$ SD. Thus male gender, high socioeconomic condition, increased duration of breast feeding and stunting were significantly associated with overweight/obesity in preschool children.
\end{abstract}

Keywords: BMI Z score, Stunting, Allergic disorders, Preschool children, Obesity

\section{Introduction}

Pediatric overweight and obesity have increased worldwide [1]. It is linked with increased risk of long-term ailments in adulthood [2]. Prevalence of overweigh and Obesity in developed countries is higher compared with developing regions of the world [3]. Overweight tended to be more common among girls, particularly in developing countries [4]. Associations between asthma and high BMI have been observed in studies of children and adults $[5,6]$. This study focused on exploring the possible associations between socio-demographic, personal and clinical characteristics with overweight/obesity in preschool children.

\footnotetext{
*Correspondence: drfathimhelgamal1996@hotmail.com

1 Department of Family Medicine, Ibn Sina National College for Medical Studies, Al Mahjer Street, P.O. Box 31906, Jeddah 21418, Kingdom of Saudi Arabia

Full list of author information is available at the end of the article
}

\section{Main text Methods}

This is a cross-sectional study, where a convenient sample of preschool children who visited the outpatient clinics with their relatives, but not as patients, in two hospitals during 2 month-period was selected. One hospital was in the North of Jeddah, which serves a well off community with high socioeconomic level, while the other hospital was in the South of Jeddah city, which serves a community with low socioeconomic level. The total number of children examined was 748; this number was greater than the required minimum number for such a study (220 children) [7]. Data was collected from children's mothers after taking an informed written consent. Data was collected through: (1) questionnaire: which provided information about personal and socio-demographic characteristics, feeding patterns, and clinical characteristics of the child; (2) anthropometry: weights and lengths/heights of the children and their mothers according to standard procedures.

(c) The Author(s) 2020. This article is licensed under a Creative Commons Attribution 4.0 International License, which permits use, sharing, adaptation, distribution and reproduction in any medium or format, as long as you give appropriate credit to the original author(s) and the source, provide a link to the Creative Commons licence, and indicate if changes were made. The images or other third party material in this article are included in the article's Creative Commons licence, unless indicated otherwise in a credit line to the material. If material is not included in the article's Creative Commons licence and your intended use is not permitted by statutory regulation or exceeds the permitted use, you will need to obtain permission directly from the copyright holder. To view a copy of this licence, visit http://creativeco mmons.org/licenses/by/4.0/. The Creative Commons Public Domain Dedication waiver (http://creativecommons.org/publicdomain/ zero/1.0/) applies to the data made available in this article, unless otherwise stated in a credit line to the data. 
Anthropometric analysis: The variables age, sex, weight and height were used. These measurements were used to provide the following indices: weigh-for-age, heightfor-age, weight-for-height, and BMI for age. The indices generated were compared to standard reference values of WHO to obtain the corresponding Z-scores [8]. We used Z-scores to determine the nutritional status of the children. A child whose height-for-age Z-score was $<-2$, from the median value of the reference population, was considered as stunted. The children with BMI/ Age Z-score $>+2 \mathrm{Z}$ to $+3 \mathrm{Z}$, from the median value of the reference population, were classified as overweight; and if it was $>+3 \mathrm{Z}$, obese.

3-ISAAC core questionnaire on asthma and allergy: It is used to diagnose bronchial asthma, allergic rhinitis and atopic eczema [9].

Data analysis and statistical tests: The data was analyzed using the Statistical Package for Social Sciences (IBM SPSS, version 23, Armonk, NY: IBM Corp.). The Multi-nominal Logistic regression method was used where BMI/Age $\mathrm{Z}$ score $>+2 \mathrm{SD}$ was used as the dependent dichotomous variable and other variables were used as the independent dichotomous variables, where Odds ratios, 95\% confidence interval (95\% $\mathrm{CI})$, and $\mathrm{p}$ values were calculated. The Linear Multiple Regression Analysis was used to study the continuous variables that could significantly predict the BMI/Age Z Score. The level of significance was .05.

\section{Results}

The males were 357 (47.7\%), and 391 were females (52.3\%). The BMI/age Z score $>+2$ SD was found in 146 children (19.6\%). Among the studied children 64 were overweight $(8.6 \%)$, while 82 were obese $(11.0 \%)$. The Mean age of the children who have BMI/Age Z score $>+2$ SD was 29.19 months (SD 19.92), compared to 34.69 months (SD 20.79) for children who have BMI/ Age $\mathrm{Z}$ score $\leq 2 \mathrm{SD}$ (t-test $=2.887, \mathrm{p}<.004)$. The BMI/ Age Z Score $>+2$ SD was significantly more encountered among children in the Northern region compared to children in the Southern region of Jeddah (OR: 2.43; 95\% CI $1.54,3.84$, and $\mathrm{p}<.000$ ). The BMI/age $\mathrm{Z}$ score $>2 \mathrm{SD}$ was found in $23.8 \%$ of the males, while it was recorded in $16 \%$ of the females. The BMI/Age Z score $>+2$ SD was significantly more common among the males compared to the females (OR 1.76; 95\% CI 1.09, 2.8, and $\mathrm{p}<.02)$. However, the other socio-demographic factors like parents educational level, their occupation, or their monthly income were irrelevant to BMI Z score $>+2 \mathrm{Z}$ among the studied children. The types of food administered to the children were irrelevant to $\mathrm{BMI} /$ Age $\mathrm{Z}$ scores $>+2 \mathrm{SD}$ (Table 1). The younger children have significantly higher values of BMI/Age Z-scores compared with the older ones $(b=-.013, p<.004)$. The family size, and the rank of the child among his siblings were, also, not significant determinants of the child BMI/Age $\mathrm{Z}$ score. The increased duration of breast feeding in infancy, was significantly associated with the increase in BMI Z-score $(b=.027$,

Table 1 Logistic regression of the different independent variables on BMI/Age Z Score over 2 SD

\begin{tabular}{|c|c|c|c|c|c|}
\hline \multirow[t]{2}{*}{ Independent variables } & \multirow[t]{2}{*}{ B } & \multirow[t]{2}{*}{ Sig. } & \multirow[t]{2}{*}{$\operatorname{Exp}(B)$} & \multicolumn{2}{|c|}{ 95\% Confidence Interval for $\operatorname{Exp(B)}$} \\
\hline & & & & lower bound & Upper bound \\
\hline Intercept & 1.765 & .001 & & & \\
\hline Area of residence & .890 & .000 & 2.434 & 1.543 & 3.841 \\
\hline Nationality & -.089 & .664 & .915 & .613 & 1.366 \\
\hline Gender & .570 & .022 & 1.768 & 1.086 & 2.879 \\
\hline Educational level of the father & .157 & .467 & 1.170 & .766 & 1.786 \\
\hline Monthly income & .104 & .672 & 1.109 & .686 & 1.793 \\
\hline Educational level of the mother & -.049 & .824 & .953 & .621 & 1.460 \\
\hline Occupational of the father & .053 & .814 & 1.054 & .680 & 1.633 \\
\hline Occupational of the mother & .110 & .657 & 1.116 & .688 & 1.811 \\
\hline Monthly income & .104 & .672 & 1.109 & .686 & 1.793 \\
\hline Gestational period & -.208 & .543 & .812 & .415 & 1.588 \\
\hline Main feeding in infancy & -.034 & .868 & .966 & .645 & 1.448 \\
\hline Eat food with preservatives, daily & -.176 & .461 & .839 & .526 & 1.338 \\
\hline Eat sweet food daily & -.097 & .668 & .907 & .582 & 1.414 \\
\hline Drink milk, daily & -.079 & .752 & .924 & .567 & 1.507 \\
\hline Eat fruits and vegetables, daily & -.344 & .191 & .709 & .423 & 1.187 \\
\hline Treatment for anemia & .030 & .947 & 1.031 & .425 & 2.497 \\
\hline
\end{tabular}


$\mathrm{p}<.004)$. The children with stunted growth were 6.7 times fold more likely to have BMI/age Z Score > + 2 SD compared to the normal children (OR 6.73; 95\% CI 3.79, 10.80 , and $\mathrm{p}<.000$ ), after controlling for the other factors. The BMI/Age $\mathrm{Z}$ score $>+2$ in the children was independent of the BMI for their mothers (Table 2), and was, also, independent of having asthma, or allergic rhinitis, or eczema or other infections (Table 3 ).

\section{Discussion}

Early years of life is a critical period for evaluating the onset of obesity and application of control strategies; as increased BMI in childhood is linked to obesity and ill health in later years [10]. The weight of children naturally fluctuates during growth, and so assessment of BMI in pediatric age groups necessitates the availability of reference charts which consider gender and age. A child with BMI for age and gender Z-score that is $>2$ SD from the median of the reference population is classified as overweight, and if it is $>3 \mathrm{SD}$ is considered obese [8]. The main objective of the present study was to assess the prevalence and determinants of $\mathrm{BMI} /$ age $\mathrm{Z}$ score $>2 \mathrm{SD}$ among preschool children in Jeddah city KSA, using the WHO Child Growth Standards. Based on data collected from sample of the child population in Jeddah city KSA it was found that approximately $20 \%$ of preschool children have $\mathrm{BMI} /$ age $\mathrm{Z}$ score $>2 \mathrm{SD}$. This is contradicting to a previous study [11] who revealed that the overall prevalence of overweight in preschool children in developing countries was low (3.3\%) [12]. Findings of the present study, also, are comparable to other countries [13]. Previous study revealed that $29.6 \%$ of preschool children were overweight, and $11.1 \%$ were obese with the prevalence of obesity being significantly higher for boys than girls [14]. The present study also, found increased prevalence of $\mathrm{BMI} /$ age $\mathrm{Z}$ score $>2 \mathrm{SD}$ in males compared to females. In the present study, after allowing for the confounding factors, children living in the economically developed North region of Jeddah city were more likely to become obese compared to the less economically developed South region of Jeddah. In the present study, parental education or occupation were not significant predictors of BMI/ age $\mathrm{Z}$ score over $2 \mathrm{SD}$ in the studied children. These findings are supported by a previous study [4]. In the present study, gender and age of the preschool children were significantly associated with having BMI/age $\mathrm{Z}$ score $>2$ $\mathrm{SD}$, while other variables like family size, ranking of the child, smoking habits of the parents, birth weight, feeding of the child during infancy and dietary habits were not significant. In a meta-analysis study, it was found that duration of breastfeeding was inversely and linearly associated with the risk of overweight. The risk of overweight was reduced by $4 \%$ for each month of breastfeeding [15]. Nevertheless, in the current study, after allowing for confounding factors, we got contradicting results, where prolonged breast feeding was associated with increased BMI Z score among Saudi children. Previous studies found significant link between sugary drink consumption and weight gain in children [16, 17]. However, the present study did not find daily consumption of sweet food, intake of milk or fruits and vegetables as significant predictors of $\mathrm{BMI} /$ age $\mathrm{Z}$ score $>2 \mathrm{SD}$.

In the present study, although, asthma was positively associated with increased BMI Z score, this association disappeared when logistic regression was used to allow for the effects of different socio-demographic and clinical factors. Findings of the present research were supported by other study [18]. Although, previous study claimed positive association between obesity and both allergic rhinitis and eczema [19], yet the present study, failed to find such an association. Stunting is prevalent in many developing countries; it is a possible risk factor for being overweight, as it may cause a series of longlasting changes, such as reduced energy expenditure, increased risk to the effects of a high-fat diet, reducedfat oxidation, and impaired regulation of food intake [20]. In the present study it was found that increased BMI/Age Z Score $>2$ SD was significantly associated with the stunting in preschool children.

Table 2 Multiple regression of independent variables and BMI/Age Z-Score

\begin{tabular}{|c|c|c|c|c|c|}
\hline & \multicolumn{2}{|c|}{ Unstandardized coefficients } & \multirow{2}{*}{$\begin{array}{l}\text { Standardized } \\
\text { coefficients } \\
\text { Beta }\end{array}$} & \multirow[t]{2}{*}{$\mathbf{t}$} & \multirow[t]{2}{*}{ Sig. } \\
\hline & B & Std. error & & & \\
\hline (Constant) & .328 & .442 & & .742 & .458 \\
\hline Age (Months) & -.013 & .004 & -.139 & -2.915 & .004 \\
\hline Number of children in the family & -.185 & .132 & -.137 & -1.405 & .161 \\
\hline Rank of the child among his siblings & .122 & .132 & .089 & .923 & .357 \\
\hline Duration of main feeding in infancy & .027 & .010 & .129 & 2.872 & .004 \\
\hline $\mathrm{BMI}$ of the mother & .000 & .012 & .000 & .010 & .992 \\
\hline
\end{tabular}


Table 3 Logistic regression between BMI/Age Z Score over 2 SD and allergic disorders and stunting

\begin{tabular}{|c|c|c|c|c|c|}
\hline \multirow[t]{2}{*}{ Independent variables } & \multirow[t]{2}{*}{ B } & \multirow[t]{2}{*}{ Sig. } & \multirow[t]{2}{*}{$\operatorname{Exp}(B)$} & \multicolumn{2}{|c|}{ 95\% Confidence Interval for $\operatorname{Exp(B)}$} \\
\hline & & & & Lower Bound & Upper Bound \\
\hline Intercept & -.117 & .781 & & & \\
\hline Stunting growth & 1.900 & .000 & 6.688 & 4.438 & 10.079 \\
\hline ISAAC diagnosed asthma & .129 & .588 & 1.138 & .713 & 1.817 \\
\hline ISAAC diagnosed rhinitis & .377 & .153 & 1.458 & .869 & 2.448 \\
\hline ISAAC diagnosed eczema & -.558 & .245 & .572 & .224 & 1.465 \\
\hline Repeated respiratory tract infection & -.331 & .291 & .719 & .389 & 1.328 \\
\hline Family history of allergy & .212 & .312 & 1.236 & .820 & 1.863 \\
\hline
\end{tabular}

In conclusion, the present work gives insight on the importance of increased BMI/Age in preschool children. This study demonstrated that increased BMI/Age in children can be affected by age, and socio-economic status, among other factors. The double malnutrition problem, including stunting and obesity, among preschool age children is common. Tackling increased BMI in preschool children is vital to reverse the pediatric obesity epidemic.

\section{Limitations of this study}

The limitation of this study, was that we relied, on the recall of the clinical history of the child by the mother. However, our results were very close to studies conducted in Saudi Arabia and in other parts of the world.

\section{Abbreviations}

BMI: Body mass index; SD: Standard deviation; SPSS: Statistical package for Social Sciences; Od: Odds ratio; Cl: Confidence interval; Z: SD under the normal probability distribution curve.

\section{Acknowledgements}

The authors would like to thank the Dean of the College of Ibn Sina, and the directors of outpatient clinics at both hospitals, for their material support. We would like to thank, also, all mothers and children who agreed and participated in this study.

\section{Authors' contributions}

FEl-G conceived and designed the study. FEI-G, RB, AAI-H, MAI-S, JA, WA: performed the experiment. FEl-G analysis of the data. FEI-G, RB, AAI-H, MAI-S, JA, WA Wrote the manuscript. All authors read and approved the final manuscript.

\section{Funding}

Not applicable

\section{Availability of data and materials}

Authors present the data on the main paper. The raw data is available at Ibn Sina National College for medical studies, Jeddah, KSA (researchcenter@ ibnsina.edu.sa).

\section{Ethics approval and consent to participate}

Ethical clearance was obtained from the institutional review board, Human Ethic Committee, Ibn Sina National college for Medical Studies, Jeddah, KSA (Protocol identifier 006MP25082019; Application of human ethics committee approval-2-, 17/12/2016). Permission was obtained from the directors of the outpatient clinics for collecting data from the children and their mothers. Data collection procedure was anonymous. A written consent to participate in the study was obtained from each mother of each child.

\section{Consent for publication}

Not applicable.

\section{Competing interests}

All authors declare that they have no competing interests.

\section{Author details}

1 Department of Family Medicine, Ibn Sina National College for Medical Studies, Al Mahjer Street, P.O. Box 31906, Jeddah 21418, Kingdom of Saudi Arabia.

${ }^{2}$ Ibn Sina National College for Medical Studies, Jeddah, Kingdom of Saudi Arabia.

Received: 13 December 2019 Accepted: 17 March 2020

Published online: 30 March 2020

\section{References}

1. Wang Y, Lobstein T. Worldwide trends in childhood Obesity. Int J pediatr Obes. 2006;1:11-25

2. Venn AJ, Thomson RJ, Schmidt MD, Cleland VJ, Curry BA, Gennat HC, et al. Overweight and obesity from childhood to adulthood: a follow-up of participants in the 1985 Australian Schools Health and Fitness Survey. Med J Aust. 2007:186:458-60.

3. Lobstein T, Jackson-Leach R, Moodie ML, Hall KD, Gortmaker SL, Swinburn $\mathrm{BA}$, et al. Child and adolescent obesity: part of a bigger picture. Lancet. 2015;385:2510-20.

4. Martorell R, Kettel Khan L, Hughes ML, Grummer-Strawn LM. Overweight and obesity in preschool children from developing countries. Intl J Obes. 2000:24:959-67.

5. von Mutius E, Schwartz J, Neas LM, Dockery D, Weiss ST. Relation of body mass index to asthma and atopy in children: the National Health and Nutrition Examination Study III. Thorax. 2001;56:835-8.

6. Castro-Rodriguez JA, Holberg CJ, Morgan WJ, Wright AL, Martinez FD. Increased incidence of asthma like symptoms in girls who become overweight or obese during the school years. Am J Respir Crit Care Med. 2001:163:1344-9.

7. Faul F, Erdfelder E, Lang A-G, Buchner A. G*Power 3: a flexible statistical power analysis program for the social, behavioral, and biomedical sciences. Behav Res Methods. 2007;39:175-91.

8. Onyango AW, Pinol AJ, de Onis M. Managing data for a multi-country longitudinal study: experience from the WHO Multi-center Growth Reference Study. Food Nutr Bull. 2004;25(Suppl 1):S46-52.

9. Asher MI, Keil U, Anderson HR, Beasley R, Crane J, Martinez F, et al. International study of asthma and allergies in childhood (ISAAC): rationale and methods. Eur Respir J. 1995;8:483-91.

10. McGuire S, Institute of Medicine (IOM). Early childhood obesity prevention policies. Washington, DC: The National Academies Press; 2011.

11. Onis M, Blössner M. WHO global database on child growth and malnutrition: methodology and applications. Int J Epidemiol. 2003;32(4):518-26. 
12. Xiao Y, Qiao Y, Pan L, Liu J, Zhang T, Li N, et al. Trends in the prevalence of overweight and obesity among Chinese preschool children from 2006 to 2014. PLOS ONE. 2015;10(8):e0134466.

13. Al Alawi S, Abdulatif F, Al Dhubaib D, Mohammed H, Al Ansari A. Prevalence of overweight and obesity across preschool children from four cities of the Kingdom of Bahrain. Int J Med Sci Public Health. 2013;2:529-32.

14. Lobstein TJ, James WP, Cole TJ. Increasing levels of excess weight among children in England. Int J Obes Relat Metab Disord. 2003;27:1136-8.

15. Harder T, Bergmann R, Kallischnigg G, Plagemann A. Duration of breastfeeding and risk of overweight: a meta-analysis. Am J Epidemiol. 2005;162:397-403.

16. Malik VS, Willett WC, Hu FB. Sugar-sweetened beverages and BMI in children and adolescents: re-analyses of a meta-analysis. Am J Clin Nutr. 2009;89:438-9.

17. Ludwig DS, Peterson KE, Gortmaker SL. Relation between consumption of sugar-sweetened drinks and childhood obesity: a prospective observational analysis. Lancet. 2001;357:505-8.
18. Lei $Y$, Yang $H$, Zhen L. Obesity is a risk factor for allergic rhinitis in children of Wuhan. Asia Pac Allergy. 2016;6(2):101-4.

19. Yoo S, Kim HB, Lee SY, Kim BS, Kim JH, Yu JH, et al. Association between obesity and the prevalence of allergic diseases, atopy, and bronchial hyperresponsiveness in Korean adolescents. Int Arch Allergy Immunol. 2011;154:42-8.

20. Sawaya AL. Stunting and future risk of obesity: principal physiological mechanism. Cad Saude Publica. 2003;19:S21-8.

\section{Publisher's Note}

Springer Nature remains neutral with regard to jurisdictional claims in published maps and institutional affiliations.
Ready to submit your research? Choose BMC and benefit from:

- fast, convenient online submission

- thorough peer review by experienced researchers in your field

- rapid publication on acceptance

- support for research data, including large and complex data types

- gold Open Access which fosters wider collaboration and increased citations

- maximum visibility for your research: over $100 \mathrm{M}$ website views per year

At BMC, research is always in progress.

Learn more biomedcentral.com/submissions 